\title{
THE HELOTIALES OF THE MAGADAN AND CHUKOTKA AREAS OF THE RUSSIAN ARCTIC
}

\section{A. Raitviir (†)}

Raitviir, A. 2008. The Helotiales of the Magadan and Chukotka areas of the Russian Arctic. - Sommerfeltia 31: 179-190. ISBN 82-7420-045-4. ISSN 0800-6865.

Forty-four species of Helotiales are reported from two eastern areas, Magadan and Chukotka, of the Russian Arctic. Two new genera of Dermateaceae, Arctomollisia and Larissia, and 7 new species, Arctomollisa kolymensis, Hysteronaevia vassiljevae, Larissia pyrolae, Leptotrochila chamaemori, Nimbomollisia novosieversiae, Pseudonaevia epilobii (Dermateaceae), and Gorgoniceps arctica (Helotiaceae) are described. A new combination, Arctomollisia oxyparaphysata, is proposed.

Key words: Arctic Discomycetes, distribution, new species.

Ain Raitviir (†) Laboratory of Mycology, Institute of Agriculture and Environment, Estonian Agricultural University, Riia Street 181, EE-51014 Tartu, Estonia.

\section{INTRODUCTION}

The Helotiales of the two easternmost biogeographic districts of the Russian Arctic Region, Magadan and Chukotka, are poorly known. Karatygin et al. (1999) report a single species, Lachnellula laricis (Dharne) Dennis, from the Magadan district and a lichenicolous species Llimoniella stereocaulorum (Alstrup \& D. Hawksw.) Hafellner, from Chukotka. To fill this gap the author has examined unidentified specimens collected by L. N. Vassiljeva from 1972 to 1980 from the Magadan and Chukotka areas and a small collection by L. Järva collected in 1973 from the same areas which are deposited in the Mycological Herbarium of the Estonian Agricultural University (TAA).

The examined material comprises 44 species of Helotiales of which 7 species, Arctomollisia kolymensis, Hysteronaevia vassiljevae, Larissia pyrolae, Leptotrochila chamaemori, Nimbomollisia novosieversiae, Pseudonaevia epilobii and Gorgoniceps arctica are described as new to science. Two new genera of Dermateaceae, Arctomollisia and Larissia, are described.

\section{MATERIAL AND METHODS}

The dry material was rehydrated in $2 \%$ aqueous solution of $\mathrm{KOH}$. Melzer's reagent (MLZ), Lugol's solution (LUG), ammoniacal Congo Red (CR) and Cotton Blue in lactic acid (CB), prepared accord- 
ing to Huhtinen (1989: 85), were used for histochemical reactions. A Nikon Labophot-2 microscope equipped with a drawing tube was used and all measurements and drawings were made in $2 \% \mathrm{KOH}$ if not otherwise stated. The holotypes of new species are deposited in TAA.

\section{RESULTS AND DISCUSSION}

Forty-four species of Helotiales are reported below. All are from two eastern areas, Magadan and Chukotka, of the Russian Arctic. Two new genera of Dermateaceae, Arctomollisia and Larissia, and 7 new species, Arctomollisa kolymensis, Hysteronaevia vassiljevae, Larissia pyrolae, Leptotrochila chamaemori, Nimbomollisia novosieversiae, Pseudonaevia epilobii (Dermateaceae), and Gorgoniceps arctica (Helotiaceae) are described. A new combination, Arctomollisia oxyparaphysata, is proposed.

\section{COMMENTED LIST OF SPECIES}

\section{Dermateaceae}

Arctomollisia Raitv. genus novum

Differt a Pyrenopeziza Fuckel paraphysibus lanceolatis et cellulis marginalibus longis piliformibus.

Description. Apothecia superficial, broadly sessile, scattered. Disc $0.3-2 \mathrm{~mm}$, surrounded by a distinct margin, greyish to pale ochraceous. Receptacle cup-shaped, with incurved margins when dry, externally blackish, smooth with downy margin. Ectal excipulum of textura globulosa, cells medium to dark brown, 6-9 $\mu \mathrm{m}$ in diameter, covered with abundant grana of small groups of blackish-brown opaque cells. Margin composed of a dense palisade of cylindric or cylindric-clavate, aseptate or septate outgrowths. Asci arising from croziers, cylindric-clavate to clavate, 8 -spored, apical pore blue in LUG or MLZ. Spores clavate, often slightly inequilateral, hyaline, aseptate. Paraphyses lanceolate, hyaline, without contents, exceeding the asci.

Typus generis: Mollisia oxyparaphysata Rehm.

Taxonomic notes. A peculiar dermateaceous fungus having ectal excipulum very similar to Pyrenopeziza spp., lanceolate paraphyses and a dense palisade of long, hair-like cells was present among collections by L. N. Vassiljeva. It would be unnatural to place it in Mollisiopsis Rehm because the type and other species have mollisioid excipulum without prominent grana covering the outer layer of the excipulum. Looking for similar species I discovered that Mollisia oxyparaphysata Rehm is very similar to the fungus from the Magadan area but differs from it in smaller asci and spores and differently shaped marginal hair-like cells. Dennis (1962) has combined M. oxyparaphysata into Cenangiopsis Rehm but this cannot be accepted because the type species of Cenangiopsis, $C$. quercicola (Romell) Rehm (Type in $\mathbf{S}$ studied), is clearly an encoelioid fungus belonging to the Helotiaceae whereas Mollisia oxyparaphysata (type specimen in $\mathbf{S}$ studied) is clearly a Dermateaceous species having ectal excipulum similar to Pyrenopeziza. The best solution seems to be erecting a new genus for these two species which do not fit Pyrenopeziza because of the lanceolate paraphyses 
and the structure of the apothecial margin. So the genus Arctomollisia is described and the following combination for its type species is proposed:

Arctomollisia oxyparaphysata (Rehm) Raitv. comb. nov.

(Basionymum: Mollisia oxyparaphysata Rehm, Rabenh. Krypt.-Fl. 1(3): 535, 1891.).

Arctomollisia is a segregate from Pyrenopeziza parallel to a segregate Mollisiopsis Rehm from its sister genus Mollisia. Both segregates are characterized by lanceolate paraphyses and long marginal hyphal processes or hairs. Further molecular studies would be useful to evaluate the taxonomic rank of Arctomollisia and Mollisiopsis in more detail.

Arctomollisia kolymensis Raitv. species nova

Fig. 1, a-c.

Ad Arctomollisia oxyparaphysata (Rehm) Raitv. similis sed in ascis et sporis majoribus et substrato lignicolo differt.

Description. Apothecia superficial, broadly sessile, scattered. Disc $0.3-2 \mathrm{~mm}$, surrounded by a distinct margin, greyish to pale ochraceous. Receptacle cup-shaped, with incurved margins when dry, externally blackish, smooth with downy margin. Ectal excipulum of textura globulosa, cells medium to dark brown, 6-9 $\mu \mathrm{m}$ in diameter, covered with abundant grana of small groups of blackish-brown opaque cells. Margin composed of a dense palisade of cylindric-clavate cells with apically thickened brownish walls, $30-40 \times 3.5-4.5 \mu \mathrm{m}$. Asci arising from croziers, cylindric-clavate to clavate, 8 -spored, 45-60 x 5-7 $\mu \mathrm{m}$, apical pore blue in LUG or MLZ. Spores clavate, often slightly inequilateral, hyaline, aseptate, contents homogeneous without lipid globules, 9-11 x 2.5-4 $\mu \mathrm{m}$. Paraphyses lanceolate, hyaline, without contents, exceeding the asci by $10-12 \mu \mathrm{m}$, up to $3 \mu \mathrm{m}$ wide.

Specimen examined. Magadan, Tenkinskii district, field station Kontakt, on dead sticks of Salix sp., 07.09.1975, coll. L.Vassiljeva (TAA-190020, holotype).

Diplonaevia circinata (Lib.) B. Hein

Specimen examined: Magadan, Severoevenkskii district, basin of Kegali River, on dead leaves of Carex sp., 11.08.1976, coll. L. Vassiljeva (TAA-182391).

Diplonaevia emergens (P. Karst.) B. Hein

Specimens examined: Chukotka, Bilibinskii district, basin of Bolshoi Anjui River, in the valley of Verhnii Vurguveem River, on dead leaves of Carex concolor R.Br.., 05.07.1980, coll. L. Vassiljeva (TAA-182392 \& 182393). - Chukotka, Bilibinskii district, basin of Malyi Pelidon River, on dead leaves of Carex podocarpa R. Br., 26.06.1980, coll. L. Vassiljeva (TAA-182394).

\section{Diplonaevia luzulina (P. Karst.) B. Hein}

Specimens examined: Chukotka, Bilibinskii district, basin of Malyi Anjui River, at Vorchlivyi Rivulet, on dead leaves of Luzula sp., 20.07.1980., coll. L. Vassiljeva (TAA-182395). Chukotka, Bilibinskii district, upper stream of Malyi Peledon River, at Braslet Rivulet, on dead leaves of Luzula sp., 01.07.1980., coll. L. Vassiljeva (TAA-182396).

\section{Hysteronaevia holoschoenii (De Not.) Nannf.}

Specimen examined: Chukotka, Bilibinski district, basin of Malyi Anjui River, at Rybnaja River, on dead stems of Baeothyron caespitosum (L.) A. Dietr., 23.07.1980., coll. L. Vassiljeva (TAA-182397). [Note: In the same collection Trichopezizella hystricula (Lachnaceae) was also found.]

Hysteronaevia lyngei (Lind) Nannf.

Specimens examined: Chukotka, western part of Chukotka, on dead culms of Alopecurus alpina J.E. Sm., 21.07.1977., coll. 


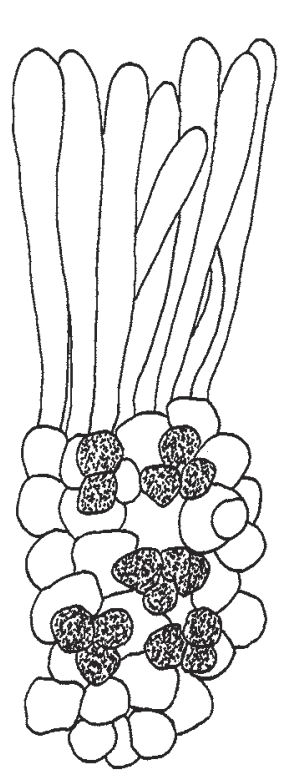

a

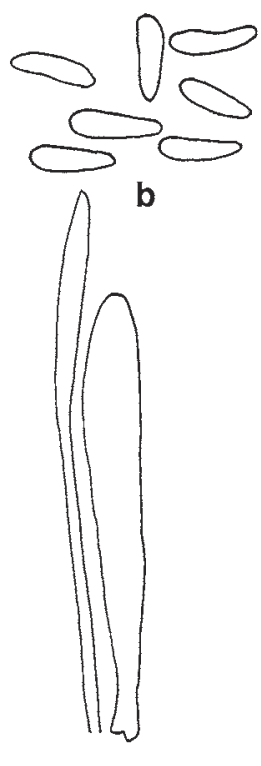

C

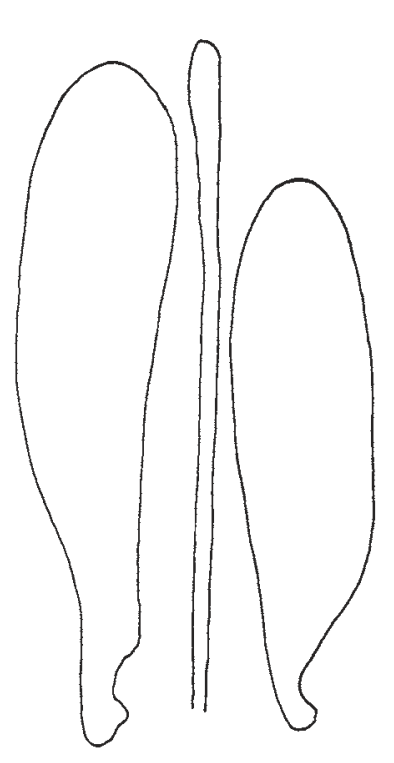

g

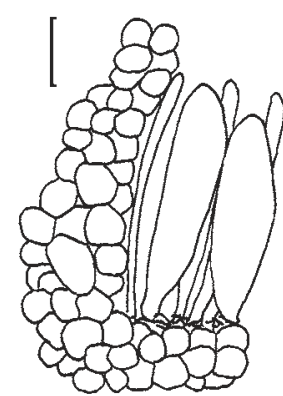

$\mathrm{h}$

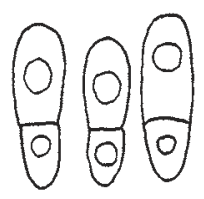

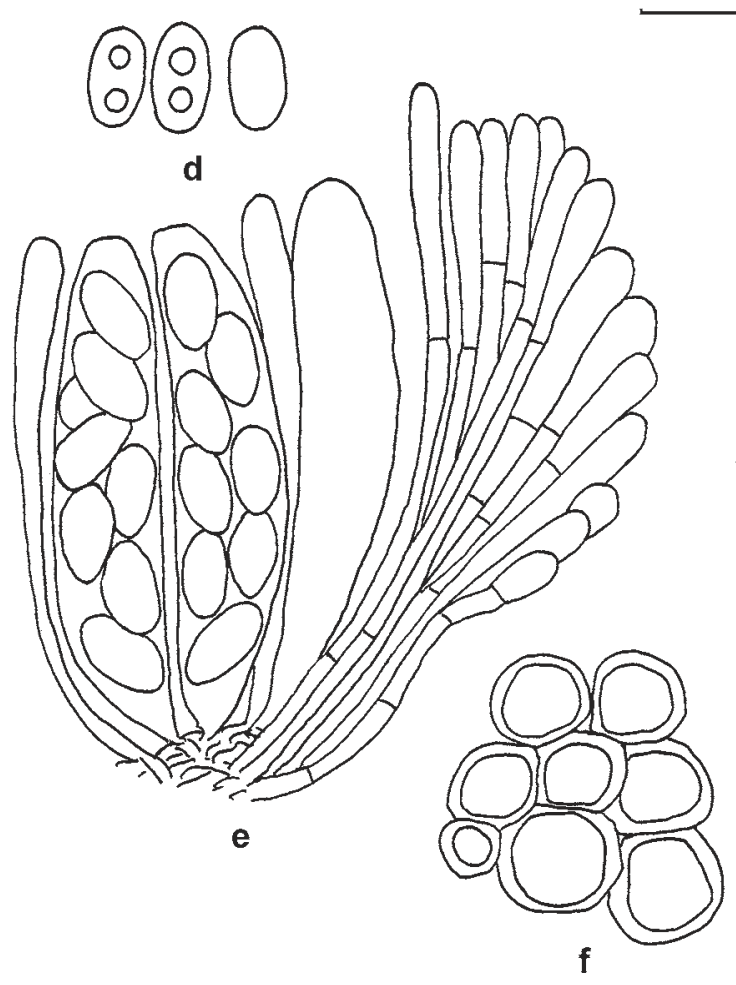

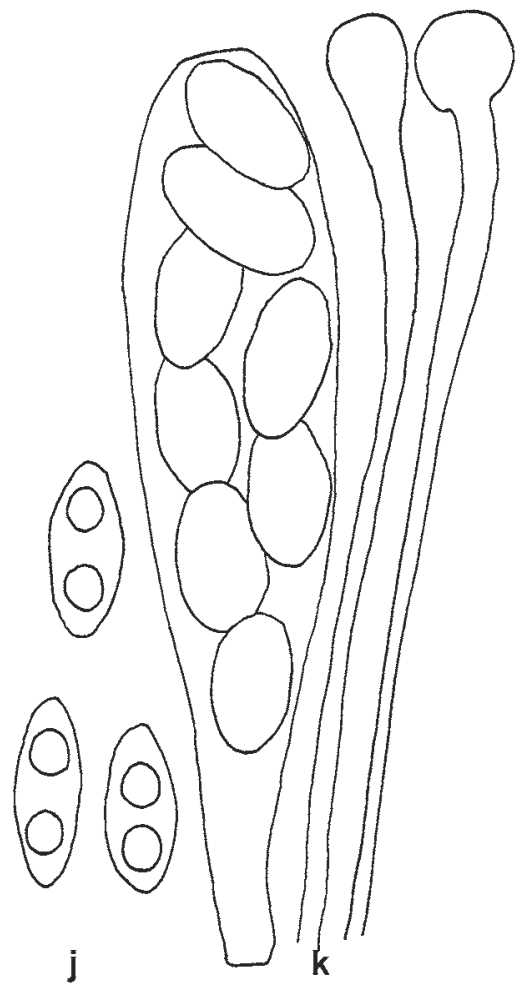

Fig. 1. a-c-Arctomollisia kolymensis, a - ectal excipulum, b-spores, $\mathrm{c}$ - ascus and paraphysis; $\mathrm{d}-\mathrm{f}$ - Larissia pyrolae, $\mathrm{d}$-spores, e - hymenium and margin of apothecium, $\mathrm{f}$ - basal excipular cells; $\mathrm{g}-\mathrm{i}$ - Leptotrochila chamaemori, $\mathrm{g}$ - asci and paraphysis, $\mathrm{h}$ - section of apothecium, $\mathrm{i}$ - spores; $\mathrm{j}-\mathrm{k}$ - Nimbomollisia novosieversiae, $\mathrm{j}$ - spores, $\mathrm{k}$ - ascus and paraphyses in cotton blue $\mathrm{Bar}=20 \mu \mathrm{m}$. 
anonymus (TAA-182398). - Chukotka, the Wrangel Island, Somnitelnaja Bay, 06.08.1979, on dead leaves of Puccinellia colpomoides Tzvel., coll. L. Vassiljeva (TAA-182399).

Hysteronaevia olivacea (Mouton) Nannf.

Specimen examined: Chukotka, the Wrangel Island, Somnitelnaja Bay, on dead stems and leaves of Carex concolor R. Br., 16.08.1979., coll. L. Vassiljeva (TAA-182400).

Hysteronaevia vassiljevae Raitv. species nova

Differt a Hysteronaevia olivacea sporis minoribus 15-18 x 4-4.5 $\mu$ m eguttulatis.

Description: Apothecia immersed to erumpent, scattered to gregarious. Disc $0.1-0.2 \mathrm{~mm}$, surrounded by a distinct margin, pale. Receptacle deeply cup-shaped, externally light brown to dark brown, smooth. Ectal excipulum of textura globulosa at the base, cells medium to dark brown, 6-10 $\mu \mathrm{m}$ in diameter, and of textura prismatica with cells arranged into radial rows at the flanks and margin. Asci arising from croziers, broadly clavate to cylindric-saccate, 8-spored, 55-80 x 10-14 $\mu \mathrm{m}$, apical pore not blue in LUG or MLZ. Spores ellipsoid fusoid to clavate, inequilateral, hyaline, aseptate, contents homogeneous without lipid globules, 15-18 x 4-5 $\mu \mathrm{m}$. Paraphyses cylindrical, $1 \mu \mathrm{m}$ wide, not exceeding the asci, apically knob-like, 2-2.5 $\mu \mathrm{m}$ wide, embedded in a hyaline slime.

Taxonomic note: This species is rather similar to H. olivacea on Carex, but has smaller spores without lipid globules and grows on Juncus.

Specimen examined: Chukotka, Bilibinski district, basin of Malyi Anjui River, at Verhnii Vurguveem River, on dead leaves of Juncus sp., 05.07.1980, coll. L. Vassiljeva (TAA-190021, Holotype).

\section{Hysteropezizella diminuens (P. Karst.) Nannf.}

Specimens examined: Chukotka, Bilibinskii district, basin of Bolshoi Anjui River, on slope of the Pyrkanei Mountain, on dead leaves of Luzula sp., 13.07.1980, coll. L. Vassiljeva (TAA-182401). - Chukotka, Bilibinskii district, basin of Bolshoi Anjui River, in valley of Rybnaja River, on dead leaves of Carex lugens H.T. Holm, 18.07.1980, coll. L. Vassiljeva (TAA-182402). - Chukotka, Bilibinskii district, basin of Bolshoi Anjui River, in valley of Shumnaja Rivulet, on dead leaves of Carex sp., 17.07.1980, coll. L. Vassiljeva (TAA-182403). - Chukotka, Bilibinskii district, basin of Bolshoi Anjui River, in the valley of Verhnii Vurguveem River, on dead leaves of Hierochloe alpina (Sw.) Roem. \& Schult., 13.07.1980, coll. L. Vassiljeva (TAA182404). - Chukotka, Bilibinskii district, at Nizhnii Ilirnei Lake, on dead leaves of Carex concolor R. Br., 21.08 .1980 \& 23.08.1980., coll. L. Vassiljeva (TAA-182405). - Magadan, Severoevenkskii district, in the vicinity of Kedon, on dead leaves of Helicotrichon dahuricum (Kom.) Kitag., 02.08.1975, coll. L. Vassiljeva (TAA-182406).

Hysteropezizella phragmitina (P. Karst. \& Starbäck) Nannf.

Specimen examined: Chukotka, Bilibinskii district, at Nizhnii Ilirnei Lake, on dead leaves of Carex rostrata Stokes, 23.08.1980., coll. L. Vassiljeva (TAA-182407).

Larissia Raitv. genus novum

Genus Dermateacearum apothecibus sessilibus obscuribus carnosibus, excipulo basaliter ex textura globulosa, lateraliter ex textura prismatica-porrecta fusco cellulis marginalis late clavatis subhyalinis, ascis poro amyloideo et sporis aseptatis fuscotunicatis distinctus.

Description: Apothecia superficial, scattered, broadly sessile, yielding a small amount of pale yellow hue when mounted in KOH. Disc pale greyish brown to yellowish brown when fresh, cinnamon brown to dark greyish brown when dry. Receptacle turbinate, externally greyish black at the base, brownish at the flanks becoming gradually paler to almost whitish at the margin. Ectal excipulum of textura globulosa at the base, cells with medium thick dark brown walls, becoming textura prismatica to textura porrecta at the flanks, cells more or less, and often irregularly, thick-walled, medium to dark brown, arranged into more or less regular rows giving rise to clavate subhyaline cells close to the margin. Asci arising from a crozier, broadly clavate, 8-spored, apical pore blue in MLZ. Spores 
ellipsoid, at first hyaline, at maturity dark brown with thick wall, aseptate, with 2 lipid globules. Paraphyses cylindric-clavate, gradually widening toward apex, not exceeding the asci, hyaline.

Typus generis: Larissia pyrolae Raitv.

Larissia pyrolae Raitv. species nova

Fig. 1, d-f.

Species apotheciis sessilis turbinatis brunneis $0.2-0.7 \mathrm{~mm}$ in diametro et alto, ascis uncinatis late clavatis poro amyloideo, 55-65 × 12-16 $\mu \mathrm{m}$, sporis ellipsoideis, aseptatis biguttulatis, primo hyalinis dein brunneotunicatis distincta.

Description: Apothecia superficial, scattered, broadly sessile, yielding a small amount of pale yellow hue when mounted in $\mathrm{KOH}$. Disc $0.2-0.7 \mathrm{~mm}$, pale greyish brown to yellowish brown when fresh, cinnamon brown to dark greyish brown when dry. Receptacle turbinate, externally greyish black at the base, brownish at the flanks becoming gradually paler to almost whitish at the margin. Ectal excipulum of textura globulosa at the base, cells with medium thick dark brown walls, 10-16 $\mu \mathrm{m}$ in diameter, becoming textura prismatica to textura porrecta at the flanks, cells more or less, and often irregularly, thick-walled, medium to dark brown, arranged into more or less regular rows giving rise to clavate subhyaline cells close to the margin. Asci arising from a crozier, broadly clavate, 8-spored, 55-65 x 12-16 $\mu \mathrm{m}$, apical pore blue in MLZ. Spores ellipsoid, at first hyaline, at maturity dark brown with thick wall, aseptate, with 2 lipid globules, 9-12 x 5-6 $\mu \mathrm{m}$. Paraphyses cylindricclavate, gradually widening towards apex, not exceeding the asci, hyaline.

Ecology: On dead leaves of Pyrola sp.

Taxonomic note: This very distinctive species on dead leaves of Pyrola is defends its status as a new genus because no other species belonging to the Dermateaceae has spores turning brown and becoming thick-walled at maturity.

Specimen examined: Chukotka, Bilibinski district, basin of Bolshoi Anjui River, on dead leaves of Pyrola sp., 25.07.1980, coll. L. Vassiljeva (Holotype in TAA-182408).

Leptotrochila cerastiorum (Wallr. ex Fr.) Schüepp

Specimen examined: Chukotka, the Wrangel Island, vicinity of the Lake Kleo, on leaves of Stellaria sp., 19.07.1979., coll. L. Vassiljeva (TAA-182409).

Leptotrochila chamaemori Raitv. species nova

Fig. 1. g-i.

Ad Leptotrochila verrucosa (Wallr.) Schüepp similis sed in sporis majoribus 15-18 x 5-6 $\mathrm{mm}$ biguttulatis uniseptatis et substratis differt. Species ab aliis generis in ascis latissimis distincta.

Description: Apothecia in small groups to gregarious, erumpent, broadly sessile. Disc $0.1-0.3$ $\mathrm{mm}$, blackish when dry. Receptacle cup-shaped to shallow cup-shaped, externally concolorous with the hymenium. Ectal excipulum of textura globulosa, cells more or less thick-walled, dark brown, 6-8 $\mu \mathrm{m}$ in diameter. Asci arising from croziers, clavate, 8-spored, 65-90 x 15-18 $\mu \mathrm{m}$, apical pore blue in LUG or MLZ, ca $3 \mu \mathrm{m}$ wide, $1.5 \mu \mathrm{m}$ high, of Mollisia-type. Spores clavate-ellipsoid, hyaline, with two big lipid globules, 1-septate, sometimes slightly constricted at the septum lower cell smaller than upper cell, 15-18 x 5-6 $\mu \mathrm{m}$. Paraphyses cylindrical, slightly exceeding the asci, apically slightly swollen up to $2.5 \mu \mathrm{m}$ wide, hyaline.

Taxonomic notes. This species has a rather peculiar combination of characters. It has erumpent, broadly sessile apothecia like L. verrucosa, which, however, differs from L. chamaemori in more slender asci and small aseptate spores. Similarly shaped two-celled spores can be found in L. ranunculi, but in this species the apothecia are completely superficial, sessile on a narrow base, and the 
asci are more slender cylindric-clavate, only up to $14 \mu \mathrm{m}$ wide. The comparatively very wide plump asci of L. chamaemori are unique in Leptotrochila,

Specimen examined: Chukotka, Bilibinski district, at Nizhnii Ilirnei Lake, on leaves of Rubus chamaemorus L., 24.06.1980., coll. L. Vassiljeva (TAA-182410).

\section{Leptotrochila svalbardensis (Lind) Spooner \& Nauta}

Specimen examined: Chukotka, the Wrangel Island, Somnitelnaja Bay, on leaves of Saxifraga hirculus L., 06.09.1979., coll. L. Vassiljeva (TAA-182411).

Mollisia benesuada (Tul.) W. Phillips

Specimens examined: Chukotka, Chaunskii district, Pevek, on dead branches of Salix sp., 03.08.1973., coll. L. Järva (TAA-46663). - Chukotka, Anadyrskii district, Shahtiorsk, on dead branches of Alnus viridis ssp. fruticosa (Rupr.) Nyman, 19.08.1973, coll. L. Järva (TAA-46694).

Mollisia hydrophila (P. Karst.) Sacc.

Taxonomic notes: Some authors use the name Belonopsis hydrophila for this species, but it is more naturally placed into Mollisia in spite of the presence of the calcium oxalate crystals in its medullary excipulum. This species is in its other excipular and all hymenial characters very similar to the typical species of Mollisia but differs from the type species of Belonopsis, B. excelsior (P. Karst.) Rehm, and other typical long-spored species of Belonopsis. In my opinion a single histochemical character which may be related to semi-aquatic lifestyle cannot be used as key character for differentiation at the generic level.

Specimen examined: Chukotka, western part of Chukotka, upper stream of Kapeliveem, on dead culms of Arctagrostis arundinacea (Trin.) Beal, 21.07.1977., coll. anonymus (TAA-182412).

Naeviopsis epilobii (P. Karst.) B. Hein

Specimens examined: Magadan, Tenkinskii district, field station Kontakt, on dead stems of Epilobium angustifolium L., 07.09.1975., coll. L. Vassiljeva (TAA-182413). - Magadan, Jagodninskii district, at Jack London Lake, on dead stems of Epilobium angustifolium L., 28.06.1974, coll. L. Vassiljeva (TAA-182414).

Nimbomollisia eriophori (Kirchn.) Nannf.

Specimen examined: Chukotka, Bilibinski district, basin of Malyi Anjui River, at Rybnaja River, on dead stems of Baeothyron caespitosum (L.) A. Dietr., 23.07.1980., coll. L. Vassiljeva (TAA-182415).

Nimbomollisia novosieversiae Raitv. species nova

Fig. $1, \mathrm{j}-\mathrm{k}$.

Species ad Nimbomollisia melatephroides similis sed in ascis majoribus, sporis latioribus aseptatis sin capsula gelatinosa et substratis differt.

Description: Apothecia superficial, scattered, broadly sessile. Disc $0.2-0.5 \mathrm{~mm}$, surrounded by a distinct margin, dark brown when fresh, blackish when dry. Receptacle shallow cup-shaped to saucer-shaped, externally brownish black to black. Ectal excipulum of textura globulosa, cells more or less thick-walled, medium to dark brown, $6-10 \mu \mathrm{m}$ in diameter. Asci arising from croziers, broadly clavate, 8-spored, 100-150 x 23-26 $\mu \mathrm{m}$, apical pore blue in LUG or MLZ, 5-6.5 $\mu \mathrm{m}$ wide, $0.5 \mu \mathrm{m}$ high, central cylinder $2.5 \mu \mathrm{m}$ wide. Spores ellipsoid-fusoid to broadly ellipsoid, hyaline, aseptate with two big lipid globules, 18-22 x 6-8 $\mu \mathrm{m}$. Paraphyses cylindrical, slightly exceeding the asci, apically abruptly swollen to capitate heads up to $12 \mu \mathrm{m}$ wide, with yellowish to pale fuscous oily contents in the apical cell and heavily incrusted with brownish-black amorphous matter forming an 
epithecium.

Specimen examined: Chukotka, Bilibinskii district, upper stream of Malyi Peledon River, on dead stems of Novosieversia glacialis F. Bolle, 27.06.1980, coll. L. Vassiljeva (Holotype in TAA-182416).

Taxonomic note: This species belongs according to its exipulum and ascus apical apparatus structures to the genus Nimbomollisia (Nannfeldt, 1983) and shows the greatest similarity to $N$. melatephroides (Rehm) Nannf.

Niptera lacustris (Fr.) Fr.

Specimen examined: Chukotka, the Wrangel Island, vicinity of the Lake Kleo, on dead culm and leaves of Alopecurus alpinus J.E. Sm., 19.07.1979., coll. L. Vassiljeva (TAA-182417).

Pseudonaevia caricina Dennis \& Spooner

Specimen examined: Chukotka, Bilibinski district, at Nizhnii Ilirnei Lake, on dead leaves of Carex concolor R. Br., 06.08.1980., coll. L. Vassiljeva (TAA-182418).

Description and illustration: Dennis \& Spooner (1993: 177, fig. 5).

Pseudonaevia epilobii Raitv. species nova

Fig. 2, a.

Pseudonaevia caricina Dennis \& Spooner similis, sed in sporis minoribus aseptatis et substratis differt.

Description: Apothecia superficial, scattered, broadly sessile. Disc $0.1-0.3 \mathrm{~mm}$, surrounded by distinct margin, brownish when fresh, dark brown when dry. Receptacle cup-shaped to shallow cupshaped, externally concolorous with the hymenium, smooth. Ectal excipulum of textura globulosa at the base, cells more or less thick-walled, medium to dark brown, 6-10 $\mu \mathrm{m}$ in diameter, and of textura prismatica-porrecta with narrow cells arranged into radial rows at the flanks and margin. Asci arising from croziers, broadly clavate, 8-spored, 90-110 x 16-22 $\mu \mathrm{m}$, apical pore blue in LUG or MLZ, 4-5 $\mu \mathrm{m}$ wide, $0.5 \mu \mathrm{m}$ high, central cylinder $1.5-2 \mu \mathrm{m}$ wide. Spores broadly ellipsoid, hyaline, aseptate, 12-16 x 5-7 $\mu \mathrm{m}$. Paraphyses cylindrical, $1 \mu \mathrm{m}$ wide, not exceeding the asci, apically slightly clavate, $1.5-2 \mu \mathrm{m}$ wide, with pale yellowish contents in apical cell.

Taxonomic note: This species has apothecia anatomically very similar to P. caricina, but its spores are distinctly smaller and the dicotyledonous host is very different from Carex.

Specimen examined: Chukotka, Bilibinskii district, upper stream of Malyi Peledon River, on dead leaves of Epilobium latifolium L., 29.06.1980, coll. L. Vassiljeva (Holotype TAA-182419).

\section{Pyrenopeziza chamaenerii Nannf.}

Specimen examined: Magadan, Tenkinskii district, field station Kontakt, on dead stems of Epilobium angustifolium L., 07.09.1975., coll. L. Vassiljeva (TAA-182420).

Tapesia lividofusca (Fr.) Rehm

Specimen examined: Magadan, Severoevenskii district, valley of Bolshaja Chaibuhha River, on a dead branch of Betula middendorfii Trautv. et Mey, 21.08.1973, coll. L. Järva (TAA-46703)

\section{Helotiaceae}

Bisporella citrina (Batsch) Korf \& S.E. Carp.

Specimen examined: Magadan, Teniuiskii district, on Kontaktnaja rivulet, on dead branches of Salix sp., 31.08.1973, coll. L. Järva (TAA-46844). 


\section{Chlorociboria aeruginascens (Nyl.) Kanouse}

Specimen examined: Magadan, Anadyrskii district, Shahtiorsk, on decaying stem of Alnus viridis ssp. fruticosa (Rupr.) Nyman, 19.08.1973, coll. L. Järva, growing together with the type specimen of Gorgoniceps arctica ( TAA-46690)

Crocicreas coronatum (Bull.) S.E. Carp.

Specimen examined: Magadan, Olskii district, mouth of the Ola River, on dead herbaceous stems, 22.08.1972, coll. L. Vassiljeva (TAA-182421).

Crocicreas cyathoideum (Bull.) S.E. Carp. var. cacaliae (Pers.) S.E. Carp.

Specimen examined: Magadan, Field Station Snezhnaja Dolina in the vicinity of Magadan, on a dead stem of Angelica saxatilis Turcz., 14.08.1972, coll. L. Vassiljeva (TAA-182422).

Crocicreas gramineum (Fr.) Fr.

Specimen examined: Chukotka, Bilibinskii district, upper stream of Malyi Peledon River, on dead culms and leaves of Poa arctica R. Br., 27.06. \& 01.07.1980, coll. L. Vassiljeva (TAA-182423 \& 182424).

Crocicreas gramineum var. incertellum (Rehm) S.E. Carp.

Specimen examined: Magadan, Severoevenkskii district, in the vicinity of Kedon, on dead leaves of Helicotrichon dahuricum (Kom.) Kitag., 02.08.1975, coll. L. Vassiljeva (TAA-182425).

Gorgoniceps arctica Raitv. species nova

Fig. 2, b-d.

Gorgoniceps hypothallosa Svrček similis, sed in colorem pallidiorem, ascis brevioribus 75-95 $x$ 7-10 $\mu \mathrm{m}$ et substratis ad lignum frondosarum differt.

Description: Apothecia superficial, scattered to crowded, sessile on a narrow base. Disc 0.3-0.8 mm, plane to shallow concave, surrounded by a distinct, minutely downy, margin, beige to pale ochraceous. Receptacle turbinate, almost as high as disc diameter, brown to dark brown at the base, becoming lighter toward margin, smooth. Ectal excipulum of textura prismatica, cells at the base more or less isodiametric, cuboid, thin-walled, medium to dark brown, $8-12 \mu \mathrm{m}$ in diameter, becoming more narrow and elongated at the flanks and terminating into cylindrical, septate outgrowths at the margin. Asci arising from croziers, clavate with conical apex, 8-spored, 75-95 x 7-10 $\mu \mathrm{m}$, small apical pore pale blue in LUG or MLZ. Spores cylindric-fusoid, straight, curved or sometimes flexuous, hyaline, with numerous small lipid guttules, becoming 1- to 3-septate, 24-30 x 2-3 $\mu \mathrm{m}$. Paraphyses cylindrical, not exceeding the asci, apically slightly clavate, $2-2.5 \mu \mathrm{m}$ wide, hyaline.

Taxonomic note: This short spored species of Gorgoniceps differs from G. hypothallosa, which has spores of the same size, in much paler apothecia, which do not turn red when mounted in KOH. Two other lignicolous species of the genus, G. aridula and G. viridula, have much longer spores and like $G$. hypothallosa grow on coniferous wood.

Specimen examined: Magadan, Anadyrskii district, Shahtiorsk, on decaying stem of Alnus viridis ssp. fruticosa (Rupr.) Nyman, 19.08.1973, coll. L. Järva (Holotype TAA-46690)

Hymenoscyphus salicellus (Fr.) Dennis

Specimen examined: Chukotka, Chukotskii district, Lavrentia, on dead branches of Salix. sp., 14.08.1973., coll. L. Järva (TAA-46680). 


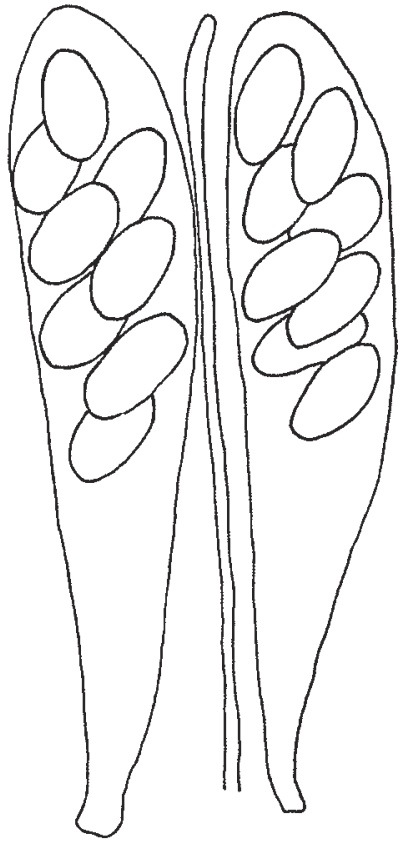

a
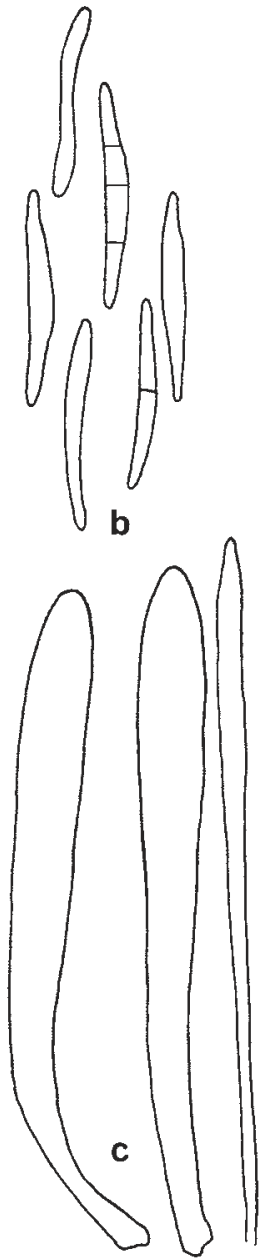

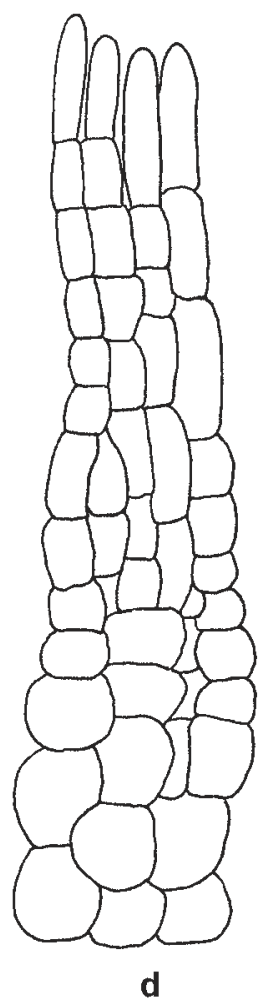

d

Fig. 2. a - Pseudonaevia epilobii, asci and paraphysis; b-d-Gorgoniceps arctica, b-spores, c-asci and paraphysis, $\mathrm{d}-$ ectal excipulum. Bar $=20 \mu \mathrm{m}$.

Neogodronia bresadolae (Rehm) Schläpfer-Bernhard

Specimen examined: Magadan, Severoevenkskii district, in the vicinity of Garmanda, on leaves of Rhododendron aureum Georgi, 18.07.1973, coll. L. Vassiljeva (TAA-182426).

\section{Phaeangellina empetri (W. Phillips) Dennis}

Specimen examined: Magadan, Jagodninskii district, basin of Jasachnaja River, on dead leaves of Empetrum sibiricum V. Vassil., 19.07.1975, coll. L. Vassiljeva (TAA-182427).

\section{Phaeohelotium flexuosum (Crossland) Dennis}

Specimen examined: Magadan, Severoevenkskii district, valley of Bolshaja Chaibuhha River, on dead branches of Salix sp., 22.08.1973, coll. L. Järva (TAA-46730). 
Tympanis laricina (Fuckel) Sacc.

Specimen examined: Magadan, Severo-Evenkski district, basin of Kegali River, on dead branches of Larix dahurica Turcz. ex Trautv.,10.08.1976., coll. L. Vassiljeva (TAA-182428).

\section{Tympanis salicina Groves}

Specimen examined: Magadan, Jagodninski district, basin of Jasachnaja River, on dead branches of Salix kolymensis Seemen, 11.07.1975., coll. L. Vassiljeva (TAA-182429).

Hyaloscyphaceae

Cistella caricis (Raitv.) Raitv.

Specimen examined: Chukotka, Bilibinski district, basin of Malyi Anjui River, at Verhnii Vurguveem River, on dead leaves of Carex concolor R. Br., 05.07.1980, coll. L. Vassiljeva (TAA-18240030).

\section{Lachnaceae}

\section{Lachnellula ciliata Dennis}

Specimen examined: Chukotka, Bilibinski district, basin of Bolshoi Anjui River, mouth ov Nizhni Vurguveem River, On dead branches of Pinus pumila (Pall.) Regel, 04.07.1980., coll. L. Vassiljeva (TAA-182431).

Lachnellula laricis (Cooke) Dharne

Specimen examined: None (no specimen preserved in TAA).

Note: Occurs in Magadan according to Karatygin et al (1999).

Lachnellula suecica (de Bary ex Fuckel) Nannf.

Specimens examined: Magadan, vicinity of Magadan City, on dead branches of Larix dahurica Turcz. ex Trautv., 1972, coll. M. Nazarova (TAA-182432). - Magadan, Olskii district, Sokol, 26.08.1973, coll. L. Järva (TAA-46786). - Chukotka, Bilibinski district, basin of Bolshoi Anjui River, at Pestsovaja River, on dead branches of Larix dahurica Turcz. ex Trautv., 09.07.1980, coll. L. Vassiljeva (TAA-182433).

\section{Lachnum impudicum Baral}

Specimen examined: Chukotka, Anadyrskii district, Shahtiorsk, on dead branches of Salix sp., 19.08.1973, coll. L. Järva (TAA-46688).

Perotia flammea Boud.

Specimen examined: Magadan, Susumanski district, in the vicinity of Susuman, on dead branches of Salix schweirinii E. Wolf, 22.06.1974., coll. L. Vassiljeva (TAA-182434). - Magadan, Tenkinskii district, Field Station Kontakt, on dead branches of Salix sp., 07.09.1979, coll. L. Vassiljeva (TAA-182435).

Trichopezizella hystricula (P. Karst.) Raitv, comb. nov.

Basionymum: Lachnum hystriculum P. Karst., Bidrag Kännedom Finlands Natur Folk 19: 182, 1871.

Syn.: Trichopezizella nidulus var. hystricula (P. Karst.) Haines

? Trichopezizella badiella (P. Karst.) Raitv. 
Specimen examined: Chukotka, Bilibinski district, basin of Malyi Anjui River, at Rybnaja River, on dead stems of Baeothyron caespitosum (L.) A. Dietr., 23.07.1980., coll. L. Vassiljeva (TAA-182436).

\section{ACKNOWLEDGEMENTS}

The author is greatly indebted to L. Vassiljeva and L. Järva for their extremely interesting and valuable collections from the high Arctic. Steen A. Elborne has critically read and improved the manuscript. The study has been supported by the Estonian Science Foundation Grant no. 5743 to the author.

\section{REFERENCES}

Dennis, R.W.G. 1962. A reassessment of Belonidium Mont. \& Dur. - Persoonia 2: 171-191.

Dennis, R.W.G. \& Spooner, B.M. 1993. The Fungi of North Hoy, Orkney - II. - Persoonia 15: 169177.

Huhtinen, S. 1990 [1989]. A monograph of Hyaloscyphaceae and allied genera. - Karstenia 29: 45-252.

Karatygin, I.V., Nezdoiminogo, E.L., Novozhilov Y.K. \& Zhurbenko, M.P. 1999. Russian arctic fungi. Check-list. - St. Petersburg.

Raitviir, A. 2004. Revised Synopsis of the Hyaloscyphaceae. - Scr. mycol. 20: 1-132. 